\title{
Dersliklerin Sesin Nesnel Parametreleri Açısından Değerlendirilmesi: KTÜ Örneği
}

\author{
Mustafa KAVRAZ ${ }^{11^{*}}$, Öznur KABİL ${ }^{2}$ \\ ${ }^{1}$ Mimarlık Bölümü, Mimarlık Fakültesi, Karadeniz Teknik Üniversitesi, Trabzon, Türkiye \\ ${ }^{2}$ Mimarlık Bölümü, Mimarlık Fakültesi, Karadeniz Teknik Üniversitesi, Trabzon, Türkiye \\ mkavraz@ktu.edu.tr
}

(Geliş/Received: 26/04/2019;

Kabul/Accepted: 28/10/2019)

Öz: Mekânların ergonomik tasarımlarında sıcaklık, nem, 1şık, ses gibi fiziksel göstergelerin optimum koşullarda sağlanması gerekmektedir. Fiziksel göstergeler arasında önemli bir yere sahip olan sesin, gürültü olarak algılanmamasının yanı sıra mekânlarda fonksiyona da bağlı olarak ișitsel sınırlar içinde algılanması gerekmektedir. Bu durumun belirlenebilmesi ise mekânlar için yapılacak akustik denetim ile gerçekleştirilebilmektedir. Bu çalışma kapsamında KTÜ İnşaat Mühendisliği 270 No'lu ve Orman Mühendisliği D-3 No'lu Dersliklerdeki akustik koşullar sesin nesnel parametrelerine göre değerlendirilmiştir. Değerlendirmeler için Odeon Version 10 Software programı kullanılmış olup çalışmada; reverberasyon süresi (RT), erken düşme süresi (EDT), belirginlik (D50), sesin anlaşılabilirlik indeksi (STI) nesnel parametreleri incelenmiştir. Öncelikle mevcut mekânlara ait nesnel parametre değerleri elde edilmiş olup optimum aralık dışında kalan parametrelerin optimum sınırlarda elde edilebilmesi için mekânların yüzeylerinde malzeme değişiklikleri yapılmıştır. Malzeme değişiklikleri sonrasında akustik açidan optimum koşullar elde edilmiştir.

Anahtar Kelimeler: akustik, derslik, sesin nesnel parametreleri, optimum koşul.

\section{Evaluation of Classrooms in terms of Objective Parameters of Sound: KTÜ Case}

\begin{abstract}
In the ergonomic design of places, physical indicators such as heat, temperature, humidity, light and sound should be provided in optimum conditions. Sound, which has an important place among the physical indicators, should not be perceived as noise but should be perceived in auditory boundaries depending on the function in places. The determination of this situation can be realized by acoustic control for the places. In this study, acoustical conditions in Classroom 270 in Civil Engineering and D-3 Classroom in Forest Engineering in KTU were evaluated according to the objective parameters of sound. Odeon Version 10 Software program were used for evaluations. In the study the objective parameters of sound which are reverberation time (RT), early fall time (EDT), clarity (D50) and the intelligibility index (STI) were investigated. Firstly, the objective parameter values of the sound were obtained for the current spaces and material changes were made on the surfaces of the spaces in order to obtain at the optimum limits to the parameters at outside the optimum range. After the material changes, the optimum conditions were obtained in terms of acoustic.
\end{abstract}

Keywords: acoustic, classroom, objective parameters of sound, optimum condition.

\section{Giriş}

Eğitim yapılarında, amacına uygun şekilde ergonomik konfor koşullarının sağlanması, faaliyetlerin etkili şelikde yürütülebilmesi açısından büyük önem taşımaktadır. Bu koşullar arasında önemli yere sahip olan akustik koşullar mekânların fiziksel özellikleri tarafından etkilenmektedir. Tasarımı gerçekleştirilen veya uygulaması tamamlanan mekânların akustik açıdan optimum koşulları sağlayıp sağlamadıklarının belirlenebilmesi için denetimlerinin yapılması gerekmektedir. Bilgisayar simülasyon, maket model ya da yerinde ölçme tekniğiyle yapılan denetimler arasında en esnek olan ve en çok tercih edilen bilgisayar simülasyon tekniğidir.

Bilimsel ya da uygulamaya yönelik çalışmalarda faklı yöntemler kullanılabilmektedir. Atça vd., [1] yapmış oldukları çalışmada, İzmir Yüksek Teknoloji Enstitüsü Matematik Bölümü Amfisinin işitsel problemlerini inceleyerek problemlerin tasarım aşamasındayken simülasyon yöntemi kullanılarak önlenebileceğini belirtmişlerdir. Gürel [2] tarafından yapılan çalışmada, Oruç Gazi İlköğretim Okulu yerleşme, bina ve yapı ölçeğinde incelenmiş ardından derslikler öznel ve nesnel olarak akustik açıdan değerlendirilmiştir. Nesnel değerlendirme, okulun her iki bloğundaki 4'er sınıfta seçilen 5 alıcı nokta için elde edilen reverberasyon süresi (RT), erken düşme süresi (EDT), sesin netliği (C80), ayırtedilebilirlik (D50), sinyal gürültü oranı (SNR) ve hızlandırılmış konuşma iletim göstergesi (RASTI) parametrelerinin 125-4000 Hz oktav band aralığında yerinde ölçüm metodu ile elde edilen sonuçlarına göre gerçekleştirilmiştir. Öznel değerlendirme ise okuldaki tüm öğretmen ve öğrencilere yapılan anket çalışması ile yapılmıştır. Yerli [3] tarafından yapılan çalışmada, Ankara İli Çankaya

\footnotetext{
* Sorumlu yazar: mkavraz@ktu.edu.tr. Yazarların ORCID Numarası: ${ }^{1} 0000-0001-9556-1916,{ }^{2}$ 0000-0002-7197-2005
} 
İlçesinde bulunan benzer hacim ve şekildeki farklı malzeme kullanımına sahip, biri özel diğeri tip proje devlet okuluna ait sınıflarda akustik konfor koşulları araştırılmıştır. Belirlenen sınıflarda 9 alıcı nokta için yerinde ölçüm metodu ile reverberasyon süresi (RT), erken düşme süresi (EDT), sesin netliği (C80), ayırtedilebilirlik (D50), ses iletim indeksi (STI), hızlandırılmış konuşma iletim göstergesi (RASTI) parametreleri ölçülmüş ve değerlendirilmiştir. Rabelo vd., [4] tarafından yapılan çalışmada, Brezilya Minas Gerais Belo Horizonte'deki 9 devlet okulunda yer alan 18 derslikte ölçülen akustik parametrelere göre öğrencilerin konuşmanın anlaşılabilirliği testindeki performansı analiz edilmiştir. Çalışmada eşdeğer ses basınç seviyesi (Leq), reverberasyon süresi (RT), ses iletim indeksi (STI) parametreleri yerinde ölçüm metodu ile ölçülmüş ve sinıfların çoğunda iyi akustik performans için önerilen standartlara uyulmadığı görülmüştür. Puglisi vd., [5] tarafından yapılan çalışmada, Yeşil Okul Proje'sinin bir parçası olarak iki faklı okuldaki sınıfların akustik kalitesinin belirlenmesi amacıyla oda akustiği göstergelerine ait alan ölçümleri ve simülasyon yöntemiyle ölçümler gerçekleştirilmiştir. Akustik kalitenin belirlenmesi amacıyla öğretmenlerin kendi raporları da çalışma kapsamında değerlendirilmiştir. Jose vd., [6] tarafından yapılan çalışmada, konuşmanın anlaşılabilirliğinin artırılması açısından sınıflarda ses yutucu malzeme kullanımının öneminden bahsedilmiş, bir örnek sınıfın ve yankılanma odasının değişik yüzeylerinde uygulanan ses yutucu malzemelerin reverberasyon süresi üzerine etkileri ölçme yöntemiyle incelenmiştir. Ses alanının az ya da çok dağınık olduğu durumlarda, köşelere ya da duvarlar ve tavan arasındaki kenarlara monte edilen ses yutucu malzemelerin daha az verimli olduğu belirlenmiştir. Kahraman ve Üçkaya [7] tarafindan yapılan çalışmada, Dokuz Eylül Üniversitesi Mimarlık Fakültesi'ndeki bir stüdyo ile bir dersliğin hacim akustiği koşulları mevcut koşullar için incelenerek değerlendirilmiştir. Değerlendirmeler öznel ve nesnel kriterlere göre yapılarak elde edilen veriler doğrultusunda çözüm önerileri yapılmıştır. Özçetin vd., [8] tarafından yapılan çalışmada, Bozok Üniversitesi İktisadi ve İdari Bilimler Fakültesi’ndeki amfilerin akustik konfor koşullarını incelenmiştir. Mekanlarda ölçme yöntemiyle elde edilen sonuçlar değerlendirilmiş ve iyileştirme çalışmaları gerçekleştirilmiştir. Mevcut durumda tuğla üzeri sıva uygulamasına sahip duvarlar iyileştirme kapsamında ipek sıva olarak değiştirilmiştir. İyileştirme sonucunda reverberasyon süresinde düşüş elde edilmiş olsa da optimum koşul elde edilememiştir.

Bu çalışma kapsamında, Karadeniz Teknik Üniversitesi Kanuni Kampüsü'nde yer alan İnşaat Mühendisliği 270 No'lu ve Orman Mühendisliği D-3 No'lu Dersliklerin akustik özellikleri ODEON version 10 bilgisayar programında belirlenerek mevcut durum için sorunlar ortaya konulmuş ve sonraki süreçte akustik sorunlar çözülmüştür.

\section{Yapılan Çalışmalar}

Sesin nesnel parametre değerlerinin elde edilmesi için kullanılan Odeon Version 10 programına aktarılmak üzere dersliklerin üç boyutlu modelleri SketchUp8'de hazırlanmıştır. Bunun için de öncelikle dersliklerin rölöveleri alınmış ve iç mekân yüzey kaplama malzemeleri belirlenmiştir.

Boyu 8,65 m, eni 8,20 m, yüksekliği 3,30 m, hacmi ise $220 \mathrm{~m}^{3}$ olan İnşaat Mühendisliği 270 No'lu Derslik 56 kişi kapasitesinde olup derslikte kişi başına yaklaşık 3,92 $\mathrm{m}^{3}$ hacim düşmektedir. Formu kare prizmaya yakın olan dersliğin zemini dökme mozaik kaplı olup duvarların ve tavanın yüzeyleri ise sıva üzerine boya kaplıdır. Dersliğin boyu doğrultusunda; koridor duvarındaki kolonlar arasında bant pencere ve bir adet ahşap kapı, dış cephe duvarındaki kolonlar arasında ise pencere yer almaktadır. Eni doğrultusundaki duvarda yazı tahtası bulunmaktadır. Şekil 1'de İnşaat Mühendisliği 270 No'lu Dersliğe ait fotoğraf ve üç boyutlu modeller yer almaktadır.

Boyu 14,80 m, eni 5,35 m, yüksekliği 3,30 m hacmi ise $250 \mathrm{~m}^{3}$ olan Orman Mühendisliği D-3 No'lu Derslik 78 kişi kapasitesinde olup, derslikte kişi başına yaklaşık $3,20 \mathrm{~m}^{3}$ hacim düşmektedir. Dikdörtgen prizma formundaki dersliğin zemini linolyum kaplıdır. Duvarların yüzeyleri ahşap, tavanın yüzeyi ise sıva üzerine boya kaplıdır. Dersliğin boyu doğrultusunda; dış cephe duvarındaki kolonlar arasında pencere, koridor duvarında ise bir adet ahşap kap1 (bir bölümü cam yüzey) yer almaktadır. Eni doğrultusundaki duvarda ise, yazı tahtası bulunmaktadır. Aydınlatma elemanı olarak sıva üstü aydınlatma armatürü kullanılmaktadır. Şekil 1'de D-3 No'lu Dersliğe ait fotoğraf ve üç boyutlu modeler yer almaktadır. 

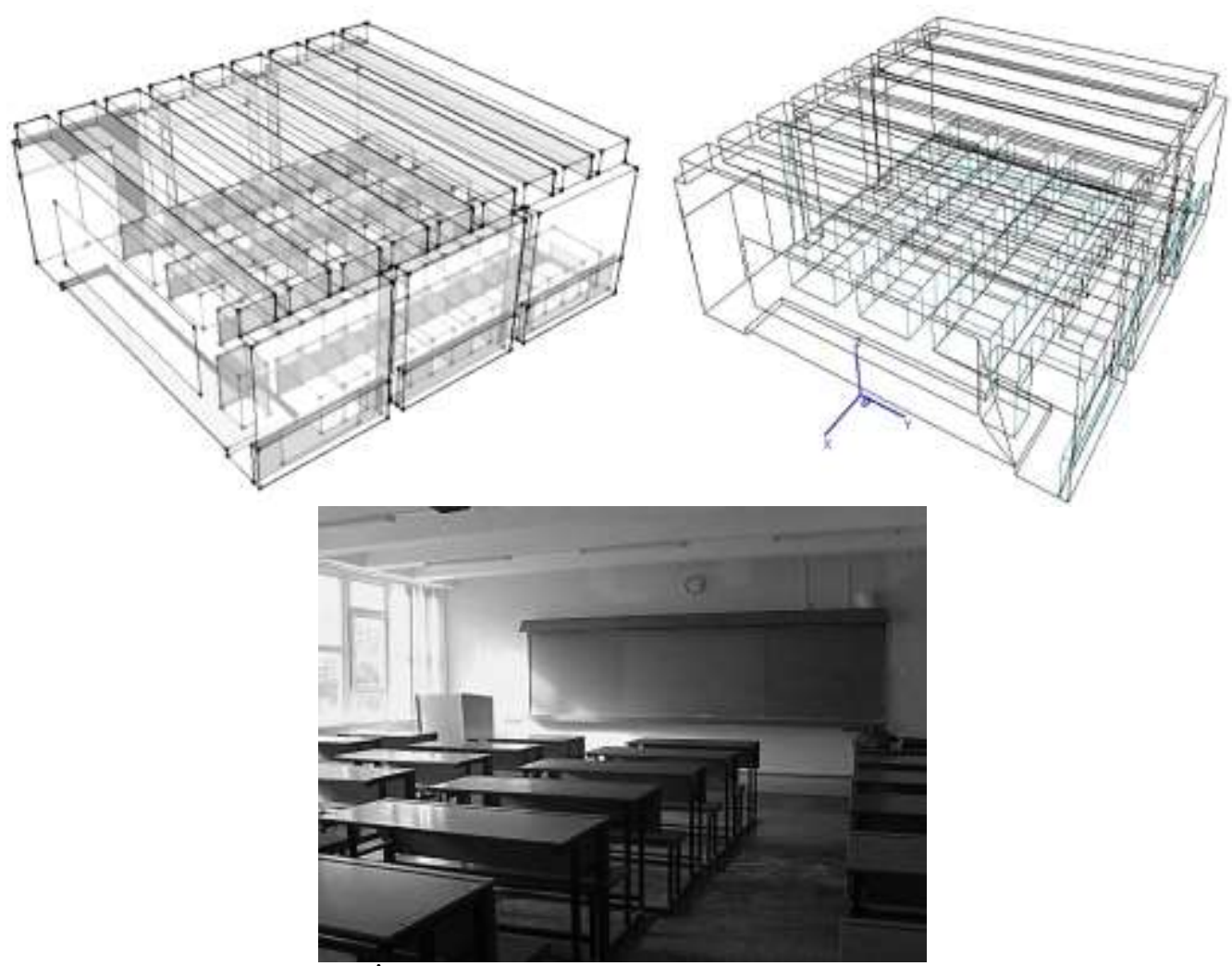

İnşaat Mühendisliği 270 No’lu Derslik
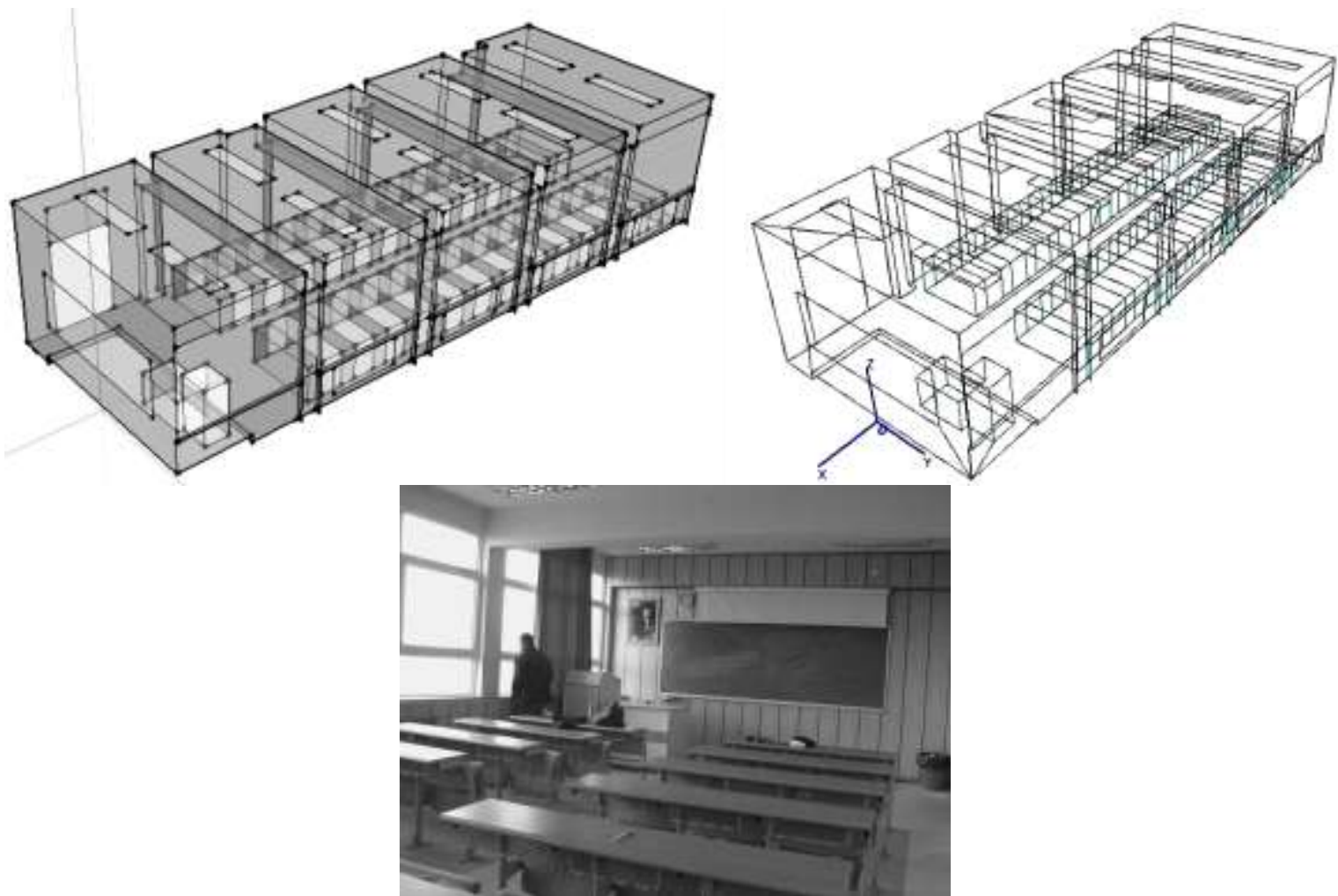

Orman Mühendisliği D-3 No’lu Derslik

Şekil 1. Desliklerin Odeon v.10 için hazırlanan modelleri ve fotoğrafları 
Dersliklerin iç mekânlarında kullanılan yüzey kaplama malzemeleri Tablo 1 ve Tablo 3 'de yer almaktadır. Sonuç değerleri optimum aralıkta elde edilemeyen sesin nesnel parametre değerlerinin optimum aralıkta elde edilebilmesi amacıyla dersliklerde yapılan iyileştirme çalışması için değiştirilen malzemeler ise Tablo 2 ve Tablo 4'de yer almaktadır.

Tablo 1. İnşaat Mühendisliği 270 No’lu Dersliğinin iç mekân yüzeylerinde kullanılan malzemeler ve 63-8000 Hz oktav bant frekans aralığındaki ses yutma katsayıları

\begin{tabular}{|c|c|c|c|c|c|c|c|c|c|c|c|}
\hline \multirow[b]{2}{*}{ NO } & \multirow[b]{2}{*}{ Yüzey } & \multirow{2}{*}{$\begin{array}{l}\text { Malzeme } \\
\text { Kodu }\end{array}$} & \multirow[b]{2}{*}{ Malzeme } & \multicolumn{8}{|c|}{ Ses yutma Katsayıları } \\
\hline & & & & $\begin{array}{l}63 \\
\mathrm{~Hz} \\
\end{array}$ & $\begin{array}{l}125 \\
\mathrm{~Hz}\end{array}$ & $\begin{array}{l}250 \\
\mathrm{~Hz}\end{array}$ & $\begin{array}{c}500 \\
\mathrm{~Hz} \\
\end{array}$ & $\begin{array}{c}1000 \\
\mathrm{~Hz}\end{array}$ & $\begin{array}{c}2000 \\
\mathrm{~Hz}\end{array}$ & $\begin{array}{c}4000 \\
\mathrm{~Hz} \\
\end{array}$ & $\begin{array}{c}8000 \\
\mathrm{~Hz} \\
\end{array}$ \\
\hline 1 & Tavan & $102^{*}$ & B.A. + Siva + Boya & 0.01 & 0.01 & 0.01 & 0.01 & 0.02 & 0.02 & 0.02 & 0.02 \\
\hline 2 & Duvar & $1001^{*}$ & Tuğla + Siva + Boya & 0.02 & 0.02 & 0.03 & 0.03 & 0.04 & 0.05 & 0.07 & 0.07 \\
\hline 3 & Dinleyici & $11007^{*}$ & Öğrenci & 0.72 & 0.72 & 0.80 & 0.86 & 0.89 & 0.90 & 0.90 & 0.90 \\
\hline 4 & Pencere & $10003^{*}$ & Çift cam & 0.10 & 0.10 & 0.07 & 0.05 & 0.03 & 0.02 & 0.02 & 0.02 \\
\hline 5 & $\begin{array}{l}\text { Öğrenci } \\
\text { Masası }\end{array}$ & $3004^{*}$ & Ahşap & 0.15 & 0.15 & 0.11 & 0.10 & 0.07 & 0.06 & 0.07 & 0.07 \\
\hline 6 & $\begin{array}{l}\text { Kap1 } \\
\text { (Ahşap) }\end{array}$ & $10007^{*}$ & Ahşap & 0.14 & 0.14 & 0.10 & 0.06 & 0.08 & 0.10 & 0.10 & 0.10 \\
\hline 7 & Kap1 (Cam) & $10001^{*}$ & Tek cam & 0.18 & 0.18 & 0.06 & 0.04 & 0.03 & 0.02 & 0.02 & 0.02 \\
\hline 8 & $\begin{array}{l}\text { Yaz1 } \\
\text { Tahtas1 } \\
\end{array}$ & $3004^{*}$ & Ahşap & 0.15 & 0.15 & 0.11 & 0.10 & 0.07 & 0.06 & 0.07 & 0.07 \\
\hline 9 & $\begin{array}{l}\text { Kalorifer } \\
\text { Peteği }\end{array}$ & $5000^{*}$ & Metal & 0.40 & 0.30 & 0.25 & 0.20 & 0.10 & 0.10 & 0.15 & 0.15 \\
\hline 10 & Denizlik & $2001^{*}$ & Mermer & 0.01 & 0.01 & 0.01 & 0.01 & 0.01 & 0.02 & 0.02 & 0.02 \\
\hline 11 & $\begin{array}{l}\text { Zemin } \\
\text { Döşemesi }\end{array}$ & $14308^{* *}$ & Dökme mozaik & 0.01 & 0.01 & 0.01 & 0.015 & 0.02 & 0.02 & 0.02 & 0.02 \\
\hline 12 & Sahne & $3004^{*}$ & Ahşap & 0.15 & 0.15 & 0.11 & 0.10 & 0.07 & 0.06 & 0.07 & 0.07 \\
\hline
\end{tabular}

Tablo 2. İnşaat Mühendisliği 270 No’lu Dersliğin iyileştirme çalışması için değiştirilen malzemeler ve 63-8000 Hz oktav bant frekans aralığındaki ses yutma katsayıları

\begin{tabular}{|l|l|l|l|l|l|l|l|l|l|l|l|}
\hline \multirow{2}{*}{ NO } & \multirow{2}{*}{ Yüzey } & \multirow{2}{*}{$\begin{array}{l}\text { Malzeme } \\
\text { Kodu }\end{array}$} & Malzeme & \multicolumn{9}{|c|}{ Ses yutma Katsayıları } \\
\cline { 5 - 13 } & & & $63 \mathrm{~Hz}$ & $\begin{array}{c}125 \\
\mathrm{~Hz}\end{array}$ & $\begin{array}{c}250 \\
\mathrm{~Hz}\end{array}$ & $\begin{array}{c}500 \\
\mathrm{~Hz}\end{array}$ & $\begin{array}{c}1000 \\
\mathrm{~Hz}\end{array}$ & $\begin{array}{c}2000 \\
\mathrm{~Hz}\end{array}$ & $\begin{array}{c}4000 \\
\mathrm{~Hz}\end{array}$ & $\begin{array}{c}8000 \\
\mathrm{~Hz}\end{array}$ \\
\hline 1 & Tavan & $4042^{*}$ & Alçıpan levha & 0.08 & 0.08 & 0.11 & 0.05 & 0.03 & 0.02 & 0.03 & 0.03 \\
\hline 11 & $\begin{array}{l}\text { Zemin } \\
\text { Döşemesi }\end{array}$ & $7004^{*}$ & Halı & 0.02 & 0.02 & 0.06 & 0.14 & 0.37 & 0.60 & 0.65 & 0.65 \\
\hline 13 & $\begin{array}{l}\text { Aydınlatma } \\
\text { Elemanı }\end{array}$ & $14306^{* *}$ & $\begin{array}{l}\text { Siva altı } \\
\text { aydınlatma } \\
\text { armatürü }\end{array}$ & 0.20 & 0.12 & 0.10 & 0.04 & 0.03 & 0.03 & 0.02 & 0.02 \\
\hline
\end{tabular}


Tablo 3. Orman Mühendisliği D-3 No'lu Dersliğinin iç mekân yüzeylerinde kullanılan malzemeler ve 63-8000 Hz oktav bant frekans aralığındaki ses yutma katsayıları

\begin{tabular}{|c|c|c|c|c|c|c|c|c|c|c|c|}
\hline \multirow[b]{2}{*}{ NO } & \multirow[b]{2}{*}{ Yüzey } & \multirow{2}{*}{$\begin{array}{l}\text { Malzeme } \\
\text { Kodu }\end{array}$} & \multirow[b]{2}{*}{ Malzeme } & \multicolumn{8}{|c|}{ Ses yutma Katsayıları } \\
\hline & & & & $\begin{array}{l}63 \\
\mathrm{~Hz} \\
\end{array}$ & $\begin{array}{l}125 \\
\mathrm{~Hz}\end{array}$ & $\begin{array}{l}250 \\
\mathrm{~Hz}\end{array}$ & $\begin{array}{c}500 \\
\mathrm{~Hz}\end{array}$ & $\begin{array}{c}1000 \\
\mathrm{~Hz} \\
\end{array}$ & $\begin{array}{c}2000 \\
\mathrm{~Hz}\end{array}$ & $\begin{array}{c}4000 \\
\mathrm{~Hz}\end{array}$ & $\begin{array}{c}8000 \\
\mathrm{~Hz}\end{array}$ \\
\hline 1 & Tavan & $102^{*}$ & B.A. + Siva + Boya & 0.01 & 0.01 & 0.01 & 0.01 & 0.02 & 0.02 & 0.02 & 0.02 \\
\hline 2 & Duvar & $3021^{*}$ & Ahşap levha & 0.30 & 0.30 & 0.20 & 0.20 & 10 & 0.05 & 0.05 & 0.05 \\
\hline 3 & Dinleyici & $11009^{*}$ & Öğrenci & 0.51 & 0.51 & 0.64 & 0.75 & 0.80 & 0.82 & 0.83 & 0.83 \\
\hline 4 & Kürsü & $3062^{*}$ & Sert kontrplak & 0.30 & 0.30 & 0.20 & 0.15 & 0.13 & 0.10 & 0.08 & 0.08 \\
\hline 5 & Pencere & $10003^{*}$ & Çift cam & 0.10 & 0.10 & 0.07 & 0.05 & 0.03 & 0.02 & 0.02 & 0.02 \\
\hline 6 & $\begin{array}{l}\text { Öğrenci } \\
\text { Masası }\end{array}$ & $3062^{*}$ & Sert kontrplak & 0.30 & 0.30 & 0.20 & 0.15 & 0.13 & 0.10 & 0.08 & 0.08 \\
\hline 7 & Kap1 & $10007^{*}$ & Ahşap & 0.14 & 0.14 & 0.10 & 0.06 & 0.08 & 0.10 & 0.10 & 0.10 \\
\hline 8 & Yazı Tahtası & $3063^{*}$ & İnce kontrplak & 0.42 & 0.42 & 0.21 & 0.10 & 0.08 & 0.06 & 0.06 & 0.06 \\
\hline 9 & $\begin{array}{l}\text { Sahne } \\
\text { Döșemesi }\end{array}$ & $3004^{*}$ & Ahşap & 0.15 & 0.15 & 0.11 & 0.10 & 0.07 & 0.06 & 0.07 & 0.07 \\
\hline 10 & $\begin{array}{l}\text { Aydınlatma } \\
\text { Elemanı }\end{array}$ & $14306^{* *}$ & $\begin{array}{l}\text { Siva üstü aydınlatma } \\
\text { armatürü }\end{array}$ & 0.20 & 0.12 & 0.10 & 0.04 & 0.03 & 0.03 & 0.02 & 0.02 \\
\hline 11 & Denizlik & $2001^{*}$ & Mermer & 0.01 & 0.01 & 0.01 & 0.01 & 0.01 & 0.02 & 0.02 & 0.02 \\
\hline 12 & $\begin{array}{l}\text { Petek Önü } \\
\text { Izgara }\end{array}$ & $40^{*}$ & Ahşap & 0.40 & 0.40 & 0.40 & 0.40 & 0.40 & 0.40 & 0.40 & 0.40 \\
\hline 13 & $\begin{array}{l}\text { Zemin } \\
\text { Döşemesi }\end{array}$ & $6000^{*}$ & Linolyum & 0.02 & 0.02 & 0.02 & 0.03 & 0.04 & 0.04 & 0.05 & 0.05 \\
\hline
\end{tabular}

Tablo 4. Orman Mühendisliği D-3 No'lu Dersliğin iyileştirme çalışması için değiştirilen malzemeler ve 63-8000 Hz oktav bant frekans aralığındaki ses yutma katsayıları

\begin{tabular}{|l|l|l|l|c|c|c|c|c|c|c|c|}
\hline \multirow{2}{*}{ NO } & \multicolumn{2}{|c|}{ Yüzey } & \multirow{2}{*}{$\begin{array}{l}\text { Malzeme } \\
\text { Kodu }\end{array}$} & Malzeme & \multicolumn{6}{|c|}{ Ses yutma Katsayıları } \\
\cline { 5 - 12 } & & & $\begin{array}{c}63 \\
\mathrm{~Hz}\end{array}$ & $\begin{array}{c}125 \\
\mathrm{~Hz}\end{array}$ & $\begin{array}{c}250 \\
\mathrm{~Hz}\end{array}$ & $\begin{array}{c}500 \\
\mathrm{~Hz}\end{array}$ & $\begin{array}{c}1000 \\
\mathrm{~Hz}\end{array}$ & $\begin{array}{c}2000 \\
\mathrm{~Hz}\end{array}$ & $\begin{array}{c}4000 \\
\mathrm{~Hz}\end{array}$ & $\begin{array}{c}8000 \\
\mathrm{~Hz}\end{array}$ \\
\hline 1 & Tavan & $4042^{*}$ & Alçıpan levha & 0.08 & 0.08 & 0.11 & 0.05 & 0.03 & 0.02 & 0.03 & 0.03 \\
\hline 10 & $\begin{array}{l}\text { Aydınlatma } \\
\text { Elemanı }\end{array}$ & $14306^{* *}$ & $\begin{array}{l}\text { Siva alt1 } \\
\text { aydınlatma } \\
\text { armatürü }\end{array}$ & 0.20 & 0.12 & 0.10 & 0.04 & 0.03 & 0.0 .3 & 0.02 & 0.02 \\
\hline 14 & $\begin{array}{l}\text { Yan ve Arka } \\
\text { Duvarlar }\end{array}$ & $8005^{*}$ & $\begin{array}{l}\text { Pamuklu } \\
\text { kumaş }\end{array}$ & 0.30 & 0.30 & 0.45 & 0.65 & 0.56 & 0.59 & 0.71 & 0.71 \\
\hline
\end{tabular}

: Odeon V10 program kütüphanesinden seçilen malzemedir [9].

** : [10]

Simülasyon süreci: SketchUp8'de hazırlanan üç boyutlu modeler Odeon Version 10 simülasyon programına aktarılarak denetim süreci başlatılmıştır. Programda öncelikle modellerin yüzeylerine genel malzeme ataması yapılmış ve yüzey birleşimlerinde hatlar denetlenmiş, ses kaçışı kontrol edilmiş ve sorunlar giderilmiştir. Kapalı kutu biçimini alan modellerin yüzeylerine programdaki kütüphaneden ve kütüphane dışından kütüphaneye alınan malzemeler atanmıştır. Program kapsamında oda akustiği hesap parametrelerine ait değerlerin atamaları gerçekleştirildikten sonra program koşturulmuş ve sesin nesnel parametrelerine ait değerler elde edilmiştir [11]. Simülasyon programı kapsamında ses kaynağı ve alıcı konumları da belirlenmiştir. Ses kaynağı; aks ekseni üzerinde konumlandırılmış ve zemin düzleminden $1.50 \mathrm{~m}$. yüksekliğe yerleştirilmiştir. Dersliklerde yer alan alıcı durumundaki öğrenciler ise plan düzleminde $0.50 \mathrm{x} 0.50 \mathrm{~m}$. gridler şeklinde tanımlanmış olup kesit düzleminde zeminden $1.20 \mathrm{~m}$. üst kotta tanımlanmışlardır. 


\section{Sesin Nesnel Parametre Değerleri}

Odeon Version 10 Simülasyon Programı ile elde edilen sesin nesnel parametre değerleri, öncelikle derslikler için belirlenen optimum değer aralıkları ile karşılaştırılmıştır. Karşılaştırma soncucunda optimum değer aralıklarında elde edilemeyen nesnel parametre değerlerinin değer aralıklarında elde edilebilmesi için yüzey malzemelerinde değişiklikler yapılmıştır.

\section{1. İnşaat Mühendisliği 270 no'lu dersliğin mevcut durumu için elde edilen sesin nesnel parametrelerinin değerlendirilmesi}

İnşaat Mühendisliği 270 No’lu Dersliğin akustik konfor koşullarının incelenmesi için kullanılan sesin nesnel parametrelerine ait optimum değer aralıkları, mekânın mevcut durumu ve iyileştirme çalışması doğrultusunda yapılan malzeme değişikliğinden sonraki durumu için Tablo 5'de verilmiştir.

Tablo 5. İnşaat Mühendisliği 270 No'lu Dersliğin mevcut ve malzeme değişikliğinden sonraki durumu için sesin nesnel parametrelerine ait optimum değer aralıkları, [12-16]

\begin{tabular}{|c|c|c|c|c|c|c|}
\hline $\begin{array}{l}\text { Hacim Akustiği } \\
\text { Parametresi }\end{array}$ & $\begin{array}{l}\text { İnşaat Mühendisliği } \\
270 \text { No'lu Derslik }\end{array}$ & \multicolumn{3}{|c|}{ Optimum (minimum) } & \multicolumn{2}{|c|}{ Optimum (maximum) } \\
\hline \multirow[t]{2}{*}{ RT } & Mevcut & \multicolumn{3}{|c|}{0,51} & \multicolumn{2}{|c|}{0,81} \\
\hline & Malzeme değişikliği & \multicolumn{3}{|c|}{0,50} & \multicolumn{2}{|c|}{0,80} \\
\hline \multirow[t]{2}{*}{$\mathrm{EDT}_{\text {mid }}$} & Mevcut & & 0,361 & & \multicolumn{2}{|c|}{0,691} \\
\hline & Malzeme değişikliği & \multicolumn{3}{|c|}{0,35} & \multicolumn{2}{|c|}{0,68} \\
\hline $\mathrm{D}_{50}$ & Her iki durum için & \multicolumn{5}{|c|}{$0,50 \leq$} \\
\hline STI & Her iki durum için & $\begin{array}{l}0-0.3 \\
\text { Kötü }\end{array}$ & $\begin{array}{c}0.3-0.45 \\
\text { Zayıf } \\
\end{array}$ & $\begin{array}{c}0.45-0.6 \\
\text { Orta } \\
\end{array}$ & $\begin{array}{c}0.6-0.75 \\
\text { İyi }\end{array}$ & $\begin{array}{c}0.75-1.0 \\
\text { Mükemmel }\end{array}$ \\
\hline
\end{tabular}

Reverberasyon Süresi (RT): Dersliğin mevcut durumu için RT değeri $500 \mathrm{~Hz}$ 'de (orta frekans bölgesi) 0,86 sn. olarak elde edilmiştir (Şekil 2). Orta hacimli mekân kapsamında incelenen ve $220 \mathrm{~m}^{3}$ hacme sahip olan dersliğin, orta frekans bölgesinde optimum RT değeri 0,51 ile 0,81 sn. aralığındadır (Tablo 5). Belirtilen değer aralıklarına göre, RT değeri optimum düzey aralığının üzerinde elde edilmiştir.

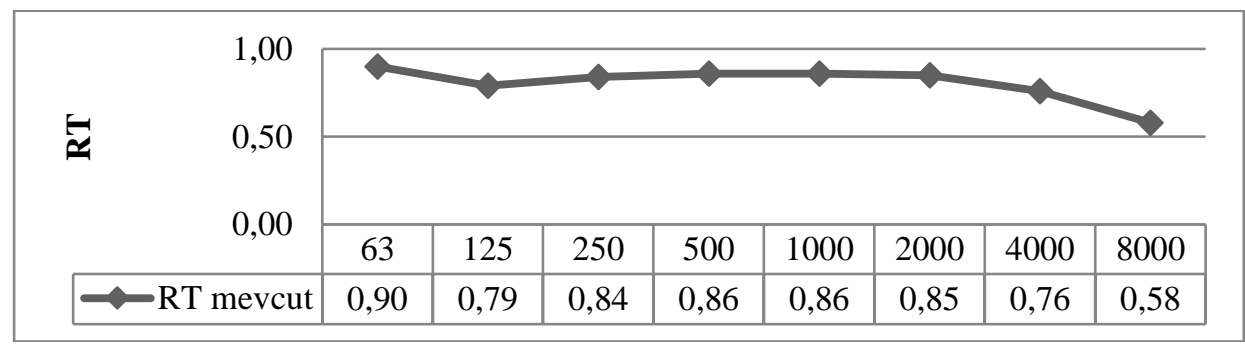

Şekil 2. Oktav band frekanslarda elde edilen RT değerleri

Erken Düşme Süresi (EDT): Dersliğin mevcut durumu için EDT değeri $500 \mathrm{~Hz}$ 'de (orta frekans bölgesi) 0,89 sn. olarak elde edilmiştir (Şekil 3). Optimum EDT değeri ise, orta frekans bölgesinde 0,361 ile 0,691 sn. aralığındadır (Tablo 5). Belirtilen değer aralığına göre, dersliğin mevcut durumu için EDT değeri, optimum düzeyin üzerinde elde edilmiştir. 


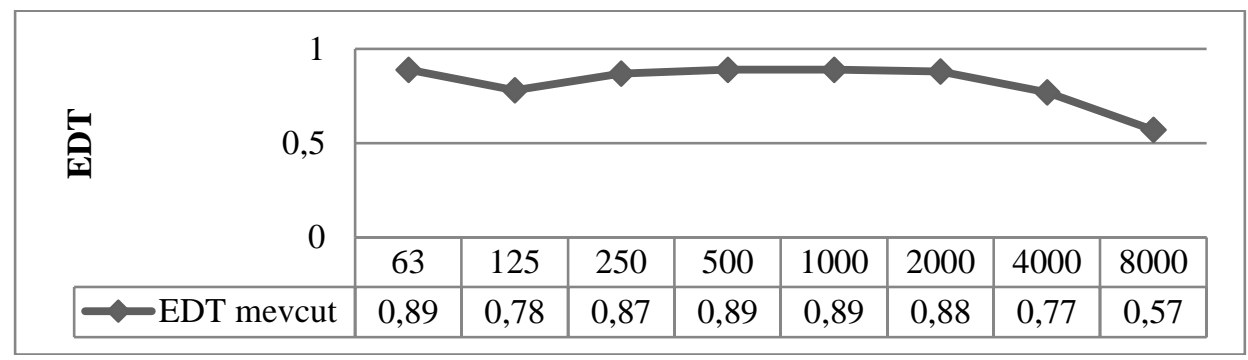

Şekil 3. Oktav band frekanslarda elde edilen EDT değerleri

Ayırt Edilebilirlik (D50): Dersliğin mevcut durumu için $\mathrm{D}_{50}$ değeri 0,57 olarak elde edilmiştir (Şekil 4). Bu değer $\mathrm{D}_{50}$ optimum alt sınır değerinin üzerindedir. Dersliğin mevcut durumu için \%50'nin üzerinde olan $\mathrm{D}_{50}$ parametresine göre, \% 90 konuşmanın belirginliğinin yeterli düzeyde olduğu belirlenmiştir.

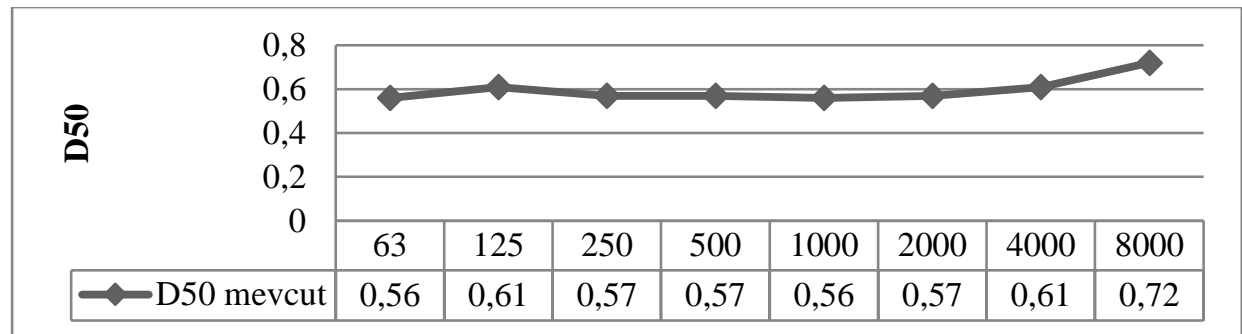

Şekil 4. Oktav band frekanslarda elde edilen D50 değerleri

Ses İletim İndeksi (STI): Dersliğin mevcut durumu için STI değeri 0,63 olarak elde edilmiştir (Şekil 5). Elde edilen STI değeri anlaşılabilirliğin iyi düzeyde olduğu 0,60 ile 0,75 aralığındadır (Tablo 5).

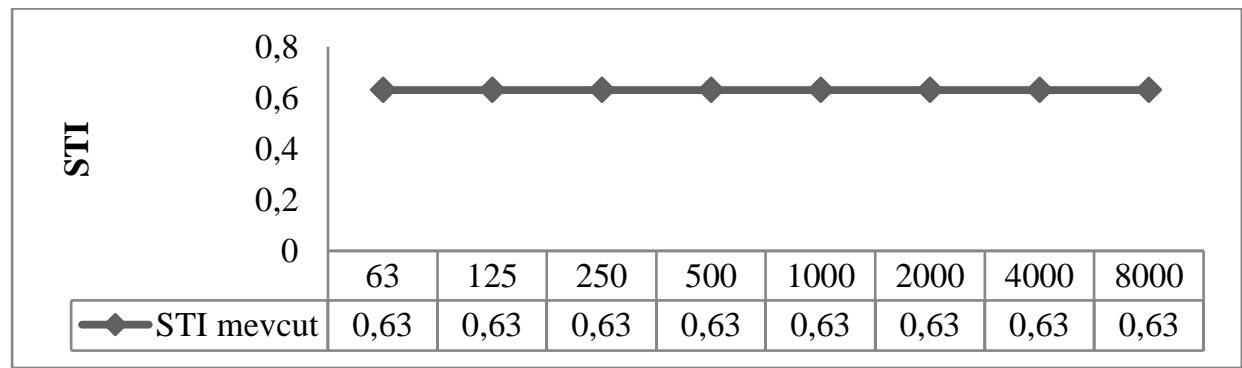

Şekil 5. Oktav band frekanslarda elde edilen STI değerleri

\section{2. İnşaat Mühendisliği 270 no'lu dersliğin için iyileştirme çalışması}

İnşaat Mühendisliği 270 No'lu Derslik için elde edilen RT, EDT değerlerini optimum düzeylere, D $_{50}$ ve STI değerlerini ise daha iyi düzeye getirmek amacıyla mekân yüzeylerinde bazı malzeme değişiklikleri yapılmıştır. Malzeme değişikliğinde; döşemede: alçak frekanslardan yüksek frekanslara yutuculukları giderek artış gösteren halı, tavanda: alçak ve orta frekanslarda ses yutuculuğu yüksek frekanslara göre fazla olan alçıpan levhalar kullanılmıştır. Tavanda kullanılan alçıpan asma tavan uygulaması ile uyumlu şekilde, sıva altı aydınlatma armatürü kullanılmıştır. İyileştirme çalışması kapsamında 270 No'lu Dersliğin Sketchup 8 programı ile yeniden modellemesi yapılmış ve ODEON V10 programında simülasyon işlemi gerçekleştirilmiştir. Elde edilen sesin nesnel parametre değerlerine göre sonuçlar tekrar değerlendirilmiştir.

Reverberasyon Süresi (RT): Malzeme değişikliği ile meydana gelen tavan formundaki değişiklik sonucunda mekânın hacmi $173 \mathrm{~m}^{3}$ 'e düşmüştür. Belirtilen hacme sahip olan bir mekândaki optimum RT değerinin 0,50 ile $0,80 \mathrm{sn}$. aralığında olması gerekmektedir (Tablo 5). Bu değer aralığına göre malzeme değişikliği sonrasında RT değeri 0,61 sn. ile optimum düzeyde elde edilmiştir (Şekil 6). 


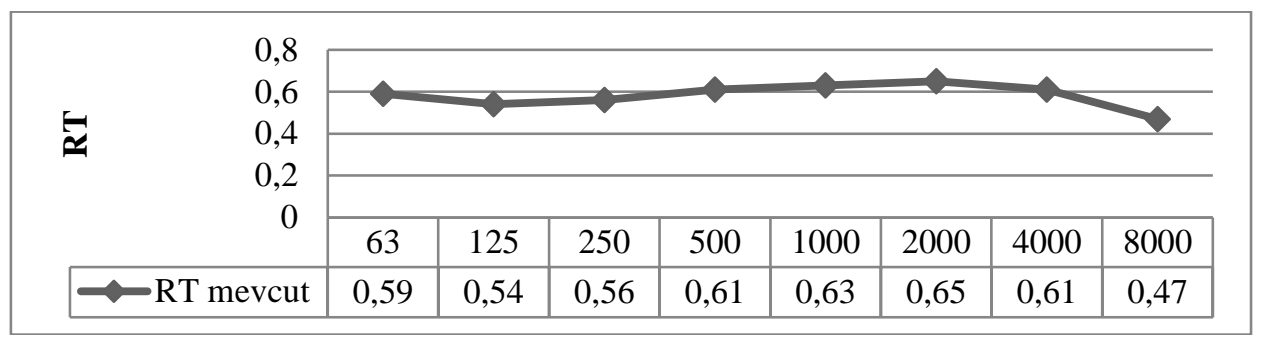

Şekil 6. Oktav band frekanslarda elde edilen RT değerleri

Erken Düşme Süresi (EDT) : Derslik için malzeme değişikliğinden sonraki optimum EDT değeri 0,35 ile 0,68 sn. aralığındadır (Tablo 5). Dersliğin mevcut durumu için optimum değer aralıklarında olmayan EDT değeri (0,89 sn.), malzeme değişikliğinden sonra 0,62 sn. ile optimum düzeyde elde edilmiştir (Şekil 7).

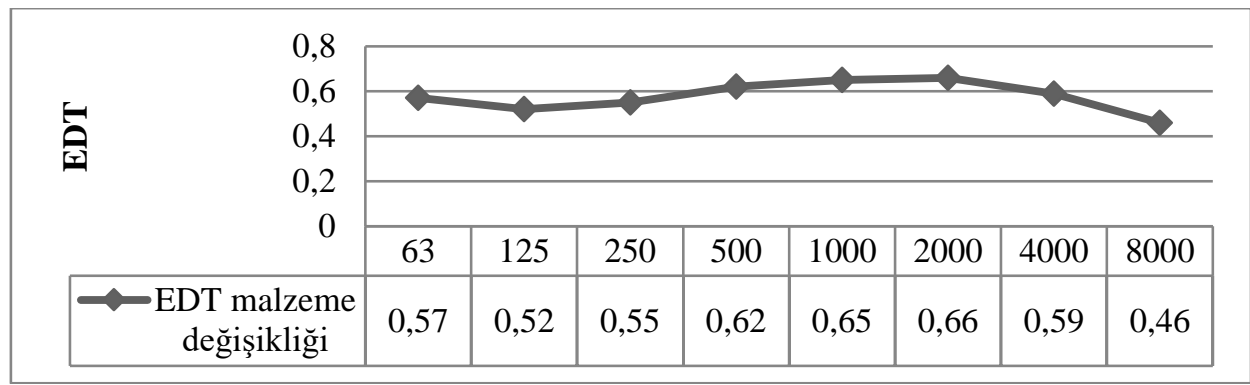

Şekil 7. Oktav band frekanslarda elde edilen EDT değerleri

Ayırt Edilebilirlik (D50): Malzeme değişikliğinden sonra elde edilen $\mathrm{D}_{50}$ değerinde $(0,71)$ mevcut durumdaki $\mathrm{D}_{50}$ değerine $(0,57)$ göre artış meydana gelmiştir (Şekil 8). Değişiklik sonrasında, derslik için konuşmanın belirginliğinin mevcut duruma göre daha iyi olduğu belirlenmiştir.

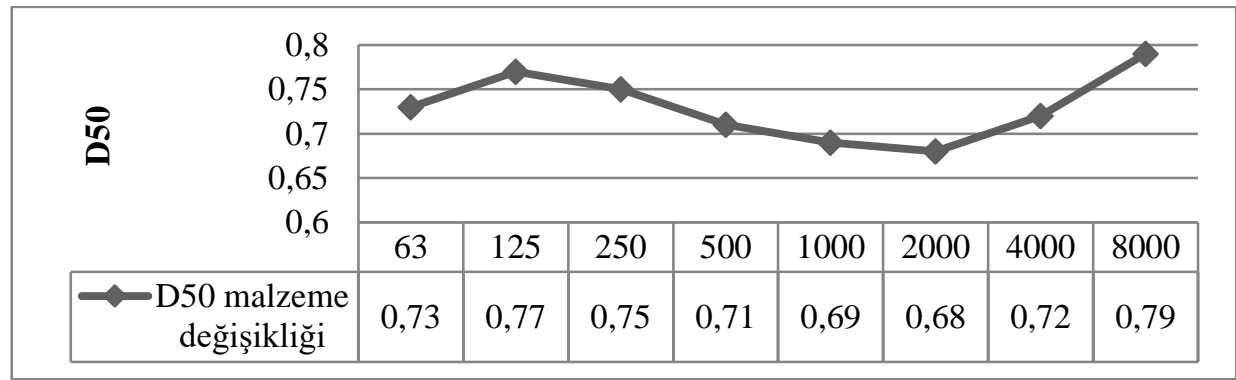

Şekil 8. Oktav band frekanslarda elde edilen D50 değerleri

Ses İletim İndeksi (STI) : Derslikte yapılan malzeme değişikliğinden sonra STI değeri $(0,71)$ anlaşılabilirliğin iyi düzeyde olduğu 0,60 ile 0,75 aralığında elde edilmiştir (Şekil 9). Bu değer mevcut durumdaki STI değerinden $(0,63)$ daha yüksek düzeydedir. 


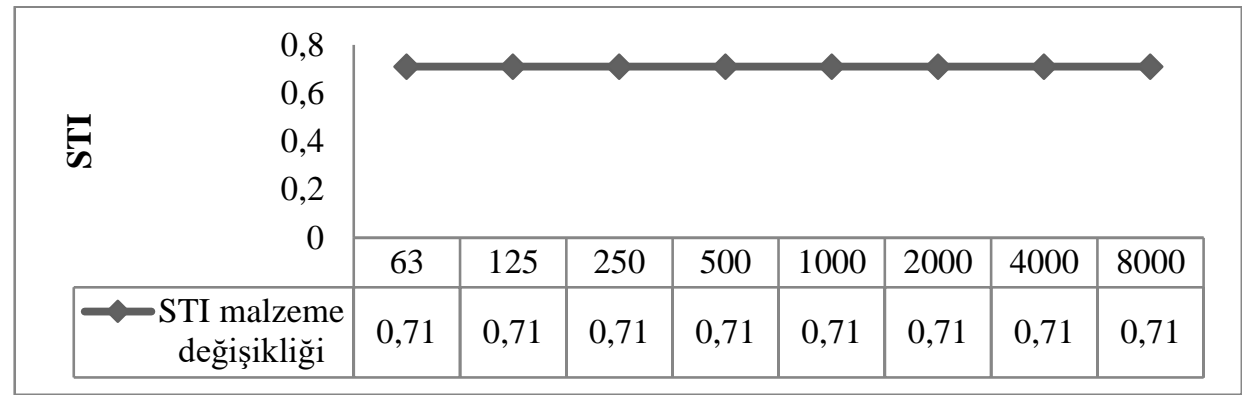

Şekil 9. Oktav band frekanslarda elde edilen STI değerleri

\subsection{Orman Mühendisliği D-3 no'lu dersliğin mevcut durumu için elde edilen sesin nesnel parametrelerinin değerlendirilmesi}

Orman Mühendisliği D-3 No’lu Dersliğin akustik konfor koşullarının incelenmesi için kullanılan sesin nesnel parametrelerine ait optimum değer aralıkları, mekânın mevcut durumu ve iyileştirme çalışması doğrultusunda yapılan malzeme değişikliğinden sonraki durumu için Tablo 6'da verilmiştir.

Tablo 6. Orman Mühendisliği D-3 No’lu Dersliğin mevcut ve malzeme değişikliğinden sonraki durumu için sesin nesnel parametrelerine ait optimum değer aralıkları, [12-16]

\begin{tabular}{|c|c|c|c|c|c|c|}
\hline $\begin{array}{l}\text { Hacim Akustiği } \\
\text { Parametresi }\end{array}$ & $\begin{array}{l}\text { Orman Mühendisliği } \\
\text { D-3 No'lu Derslik }\end{array}$ & \multicolumn{3}{|c|}{ Optimum (minimum) } & \multicolumn{2}{|c|}{ Optimum (maximum) } \\
\hline \multirow[t]{2}{*}{ RT } & Mevcut & \multicolumn{3}{|c|}{0,52} & \multicolumn{2}{|c|}{0,82} \\
\hline & Malzeme değişikliği & \multicolumn{3}{|c|}{0,52} & \multicolumn{2}{|c|}{0,82} \\
\hline \multirow[t]{2}{*}{$\mathrm{EDT}_{\text {mid }}$} & Mevcut & \multicolumn{3}{|c|}{0,372} & \multicolumn{2}{|c|}{0,702} \\
\hline & Malzeme değişikliği & \multicolumn{3}{|c|}{0,372} & \multicolumn{2}{|c|}{0,702} \\
\hline $\mathrm{D}_{50}$ & Her iki durum için & \multicolumn{5}{|c|}{$0,50 \leq$} \\
\hline STI & Her iki durum için & $\begin{array}{l}0-0.3 \\
\text { Kötü }\end{array}$ & $\begin{array}{c}0.3-0.45 \\
\text { Zayif }\end{array}$ & $\begin{array}{l}0.45-0.6 \\
\text { Orta }\end{array}$ & $\begin{array}{l}0.6-0.75 \\
\text { İyi }\end{array}$ & $\begin{array}{c}0.75-1.0 \\
\text { Mükemmel }\end{array}$ \\
\hline
\end{tabular}

Reverberasyon Süresi (RT): Dersliğin mevcut durumu için RT değeri $500 \mathrm{~Hz}$ 'de (orta frekans bölgesi) 0,71 sn. olarak elde edilmiştir (Şekil 10). Orta hacimli mekân kapsamında incelenen ve $250 \mathrm{~m}^{3}$ hacme sahip olan dersliğin, orta frekans bölgesinde optimum RT değeri 0,52 ile 0,82 sn. aralığındadır (Tablo 6). Belirtilen değer aralıklarına göre, RT değeri optimum düzeyde elde edilmiştir.

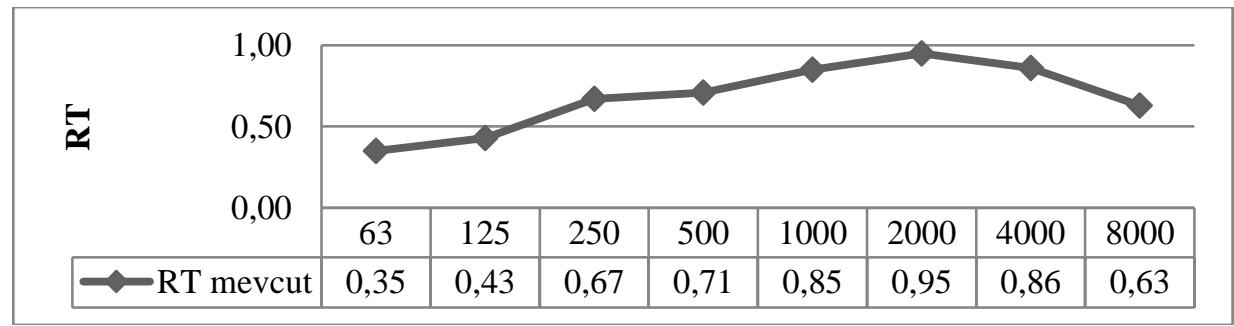

Şekil 10. Oktav band frekanslarda elde edilen RT değerleri

Erken Düşme Süresi (EDT): Dersliğin mevcut durumu için EDT değeri $500 \mathrm{~Hz}$ 'de (orta frekans bölgesi) 0,78 sn. olarak elde edilmiştir (Şekil 11). Optimum EDT değeri ise, orta frekans bölgesinde 0,372 ile 0,702 sn. aralığındadır (Tablo 6). Belirtilen değer aralığına göre, dersliğin mevcut durumu için EDT değeri, optimum düzeyin üzerinde elde edilmiştir. 


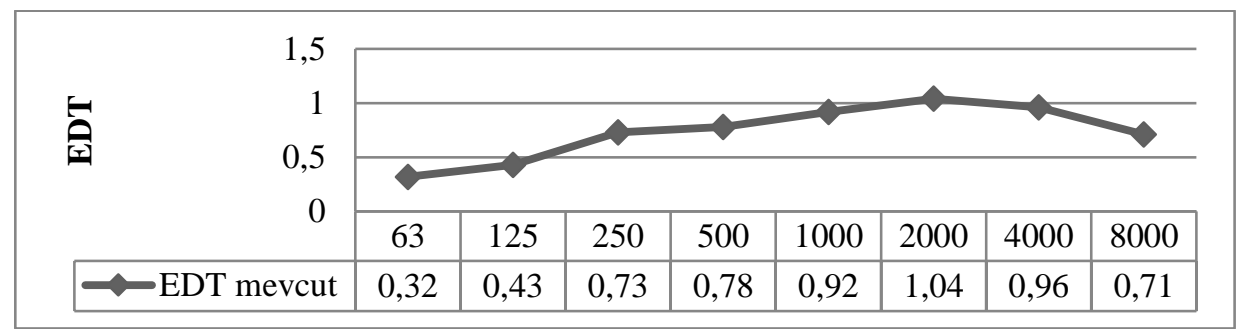

Şekil 11. Oktav band frekanslarda elde edilen EDT değerleri

Ayırt Edilebilirlik (D50) : Dersliğin mevcut durumu için $\mathrm{D}_{50}$ değeri 0,58 olarak elde edilmiştir (Şekil 12). Bu değer $\mathrm{D}_{50}$ optimum alt sınır değerinin üzerindedir. Dersliğin mevcut durumu için \%50'nin üzerinde olan $\mathrm{D}_{50}$ parametresine göre, \%90 konuşmanın belirginliğinin yeterli düzeyde olduğu belirlenmiştir.

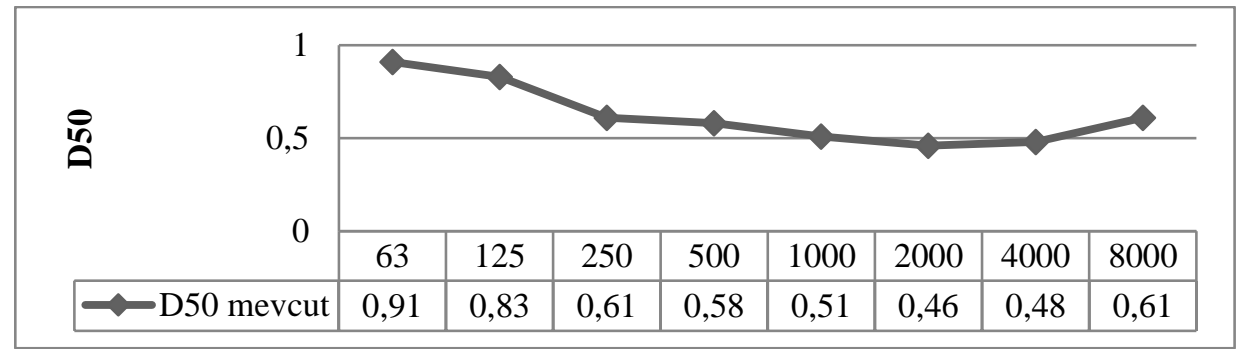

Şekil 12. Oktav band frekanslarda elde edilen D50 değerleri

Ses İletim İndeksi (STI) : Dersliğin mevcut durumu için STI değeri 0,64 olarak elde edilmiştir (Şekil 13). Elde edilen STI değeri anlaşılabilirliğin iyi düzeyde olduğu 0,60 ile 0,75 aralığındadır (Tablo 6).

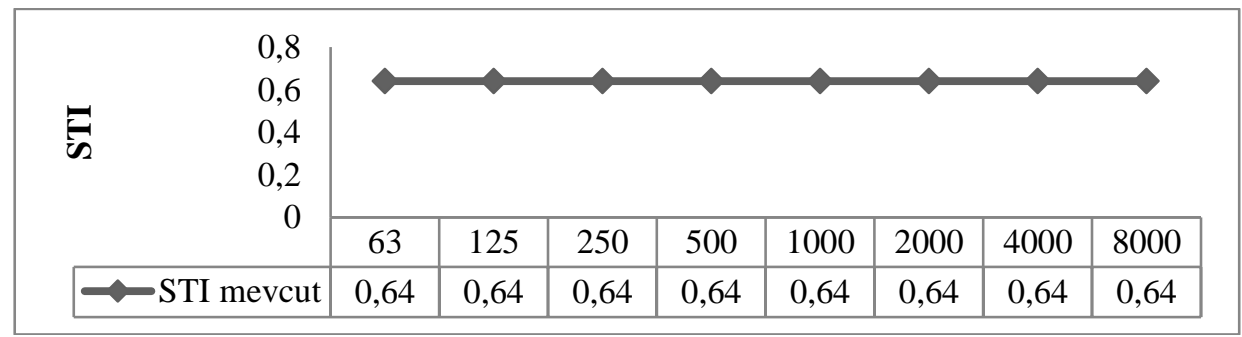

Şekil 13. Oktav band frekanslarda elde edilen STI değerleri

\subsection{Orman Mühendisliği D-3 no'lu derslik için iyileştirme çalışması}

Orman Mühendisliği D-3 No’lu Derslik için elde edilen EDT değerini optimum düzeye, $\mathrm{D}_{50}$ ve STI değerlerini daha iyi düzeylere getirmek amacıyla mekân yüzeylerinde bazı malzeme değişiklikleri yapılmıştır. Malzeme değişikliğinde; alçak frekanslardan yüksek frekanslara doğru ses yutuculukları giderek artış gösteren arka ve yan duvarlarda: yerden $90 \mathrm{~cm}$ yukarıdan başlayarak tavan yüzeyine kadar kumaş malzeme, alçak ve orta frekanslarda ses yutuculuğu yüksek frekanslara göre fazla olan tavanda: alçıpan levhalar seçilmiştir. Tavanda kullanılan alçıpan asma tavan uygulaması ile uyumlu şekilde, sıva altı aydınlatma armatürü kullanılmıştır. İyileştirme çalışması kapsamında D-3 No'lu Dersliğin Sketchup 8 programı ile yeniden modellemesi yapılmış ve ODEON V10 programında simülasyon işlemi gerçekleştirilmiştir. Elde edilen sesin nesnel parametre değerlerine göre sonuçlar tekrar değerlendirilmiştir.

Reverberasyon Süresi (RT): İyileştirme çalışması kapsamında mekânın hacminde herhangi bir değişiklik meydana gelmemiş ve bu nedenle optimum RT değerleri mevcut durumdaki gibi 0,52 ile 0,82 sn. aralığında kalmıştır (Tablo 6). Bu değer aralığına göre, malzeme değişikliği sonucunda da RT değeri (0,62 sn.) yine optimum düzeyde elde edilmiştir (Şekil 14). 


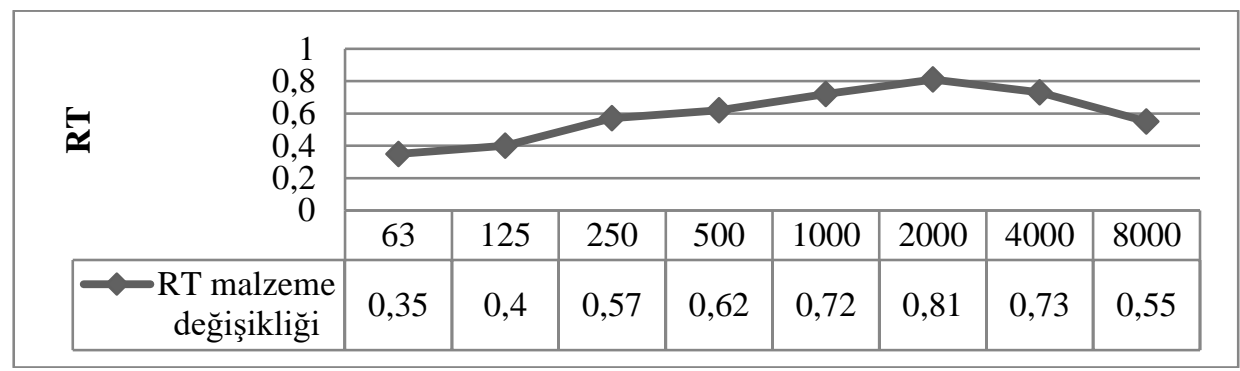

Şekil 14. Oktav band frekanslarda elde edilen RT değerleri

Erken Düşme Süresi (EDT): Derslik için malzeme değişikliğinden sonraki optimum EDT değeri mevcut durumdaki gibi 0,372 ile $0,702 \mathrm{sn}$. aralığında kalmıştır (Tablo 6). Dersliğin mevcut durumu için optimum değer aralıklarında olmayan EDT değeri (0,78 sn.), malzeme değişikliğinden sonra $0,65 \mathrm{sn}$. ile optimum düzeyde elde edilmiştir (Şekil 15).

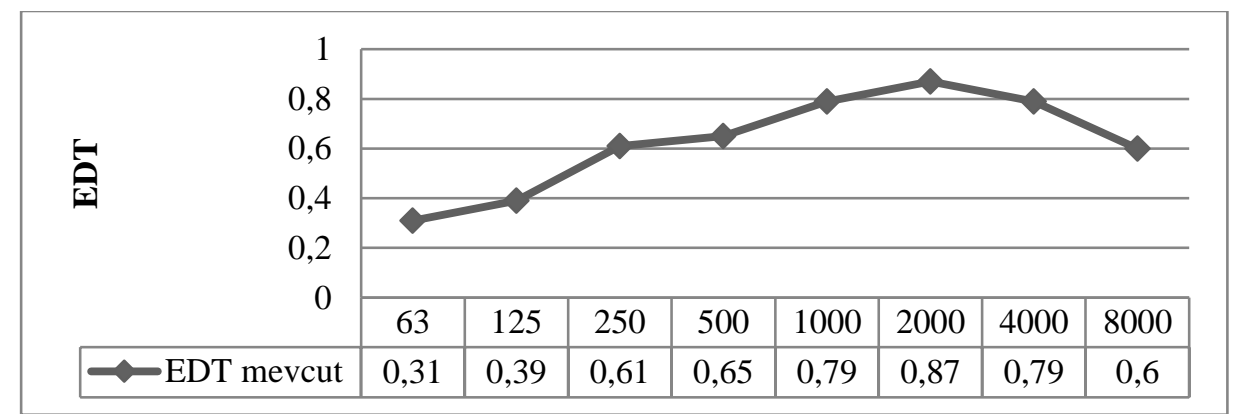

Şekil 15. Oktav band frekanslarda elde edilen EDT değerleri

Ayırt Edilebilirlik ( $\left.\mathbf{D}_{\mathbf{5 0}}\right)$ : Malzeme değişikliğinden sonra elde edilen $\mathrm{D}_{50}$ değerinde $(0,66)$, mevcut durumdaki $\mathrm{D}_{50}$ değerine $(0,58)$ göre artış meydana gelmiştir (Şekil 16). Değişiklik sonrasında, derslik için konuşmanın belirginliğinin mevcut duruma göre daha iyi olduğu belirlenmiştir.

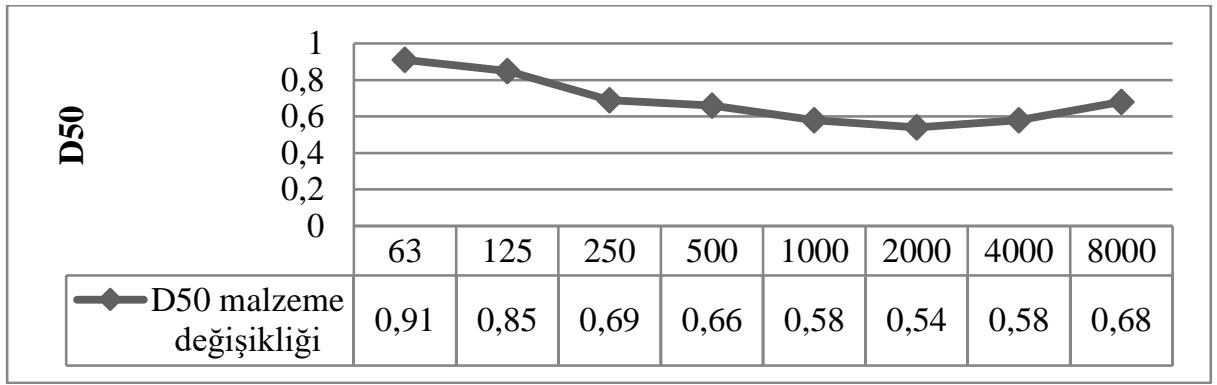

Şekil 16. Oktav band frekanslarda elde edilen D50 değerleri

Ses İletim İndeksi (STI) : Derslikte yapılan malzeme değişikliğinden sonra elde edilen STI değeri $(0,68)$ anlaşılabilirliğin iyi düzeyde olduğu 0,60 ile 0,75 aralığında elde edilmiştir (Şekil 17). Bu değer mevcut durumdaki STI değerineden $(0,64)$ biraz daha yüksektir. 


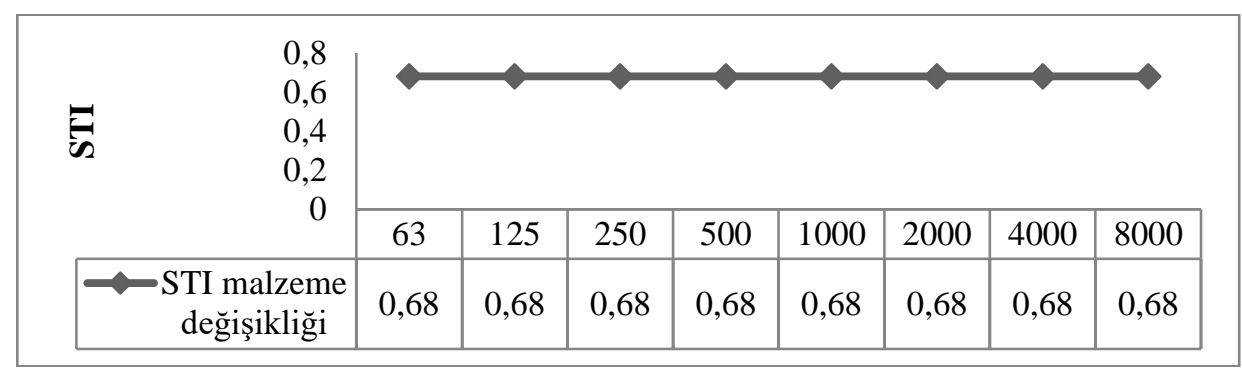

Şekil 17. Oktav band frekanslarda elde edilen STI değerleri [17]

\section{Sonuçlar}

KTÜ İnşaat Mühendisliği 270 No'lu ve Orman Mühendisliği D-3 No'lu Dersliklerdeki akustik koşullar öncelikle mekanların mevcut durumları için ODEON version10 aracılığı ile sesin nesnel parametreleri açısından değerlendirilmiştir. İnşaat Mühendisliği 270 No'lu Derslik için yapılan değerlendirmede RT ve EDT değerleri optimum sınırlar dışında elde edilmiştir. Orman Mühendisliği D-3 No'lu Derslik için yapılan değerlendirmede ise EDT değerleri optimum sınıların üzerinde elde edilmiştir. Her iki derslikte de akustik açıdan optimum değerlerin elde edilebilmesi amacıyla bazı iç mekan yüzeylerinde malzeme değişikleri yapılmıştır. Malzeme değişikliklerinde dersliklerdeki toplam ses yutuculuk etkisi dikkate alınmıştır. 270 No'lu Derslikte hem erken ve hem de geç yansımaların etkisinden dolayı, D-3 No'lu Derslikte ise erken yansımaların etkisinden dolayı belirtilen sesin nesnel parametrelerinde optimum değerler elde edilemediği için toplam ses yutuculuk etkisinin artırılması gereksinimi meydana gelmiştir. Bu doğrultuda, 270 No'lu Derslikte; tavan, zemin döşemesi ve aydınlatma elemanlarında malzeme değişiklikleri yapılmıştır. Değişikliklerle birlikte RT ve EDT değerlerinde düşüş sağlanırken bununla ters orantılı olarak D50 ve STI değerlerinde artış olmuştur. D-3 No'lu Derslikte ise; tavan, aydınlatma armatürleri ile yan ve arka duvar yüzeylerinde malzeme değişiklikleri yapılmıştır. Malzeme değişiklikleri sonucunda RT ile EDT değerlerinde düşüş D50 ile STI değerlerinde ise artış meydana gelmiştir. Her iki derslikte de D50 ile STI değerlerindeki artış sesin anlaşılabilirliğinin daha da etkili şekilde sağlanmasına katkıda bulunmuştur. Malzeme değişiklikleri ile tüm nesnel parametre değerleri optimum sınır aralılarında elde edilmiştir.

Not: Bu çalışma, 2009.120.001.1 No'lu Proje kapsamında KTÜ - BAP Birimi tarafından desteklenmiştir. Aynı zamanda, KTÜ Mimarlık Anabilim Dalında "Eğitim Yapılarındaki İç Mekânların Bilgisayar Simülasyon Yöntemi ile Akustik Açıdan İncelenmesi, Değerlendirilmesi ve Düzenlenmesi: KTÜ Örneği” isimli Yüksek Lisans Tezi kapsamında yapılmıştır.

\section{Kaynaklar}

[1] Atça E, İlal ME, Başaran T, Kazanasmaz T, Arsan ZD. Başarım odaklı tasarım: Tasarımın erken evrelerinde benzetim araçlarının önemi. 11. Ulusal Tesisat Mühendisliği Kongresi; 17-20 Nisan 2013; İzmir, Türkiye: Bildiriler Kitabı. ss. 1411-1422.

[2] Gürel N. İlköğretim okullarının akustik açıdan incelenmesi. Yüksek Lisans Tezi, İstanbul Teknik Üniversitesi Fen Bilimleri Enstitüsü, İstanbul, Türkiye, 2007.

[3] Yerli C. Farklı anlayışlarla tasarlanmış eğitim alanlarındaki sınıfların hacim akustiği yönünden değerlendirilmesi; Doğa Koleji Çukurambar ve İMKB Alparslan Ortaokulu örneği. Yüksek Lisans Tezi, Atılım Üniversitesi Sosyal Bilimler Enstitüsü, Ankara, Türkiye, 2015.

[4] Rabelo ATV, Santos JN, Oliveira RC, Magalhaes MC. Effect of classroom acoustic on the speech intelligibility of students. CoDAS 2014; 26(5): 360-366.

[5] Puglisi GE, Cutiva LCC, Pavese L, Castellana A, Bona M, Fasolis S, Lorenzatti V, Carullo A, Burdorf A, Bronuzzi F, Astolfi A. Acoustic comfort in high-school classrooms for students and teachers. Energy Procedia 2015; 78: 3096-3101.

[6] Cucharero J, Hänninen T, Lokki T. Influence of sound-absorbing material placement on room acoustical parameters. Acoustics 2019; 1: 644-660.

[7] Karaman ÖY, Üçkaya NB. Eğitim mekanlarında akustik konfor: Dokuz Eylül Üniversitesi Mimarlık Fakültesi örneği. Megaron 2015; 10(4): 503-521.

[8] Özçetin Z, Demirel F, Eminel M. Eğitim yapıları özelinde akustik konfora yönelik uygulama örneği. Social Science Development Journal 2018; 3(12): 468-475.

[9] Christensen, CL. Odeon Room Acoustics Program, Version 10. Denmark: 2001. 
[10] URL http://www.ptb.de/en/org/1/16/163/datenbank.htm, 2011

[11] Kavraz M. The effect of sound diffusers on the objective parameters of sound: the multipurpose hall of Sultanbeyli cultural center. American Journal of Scientific Research 2012; 57: 37-46.

[12] Sirel Ş. Hacim Akustiğinde Yansışım Süresi. İstanbul: Yapı Fiziği Bilim Dalı Yayınları, IDMMA Basımevi, 1981.

[13] Gade AC. Acoustical survey of eleven european concert halls. Denmark: The Acoustics Laboratory, Technical University of Denmark, Report No.44.

[14] Barron M. Auditorium Acoustics and Architectural Design. London: E \& FN Spon, 1993.

[15] Long M. Architectural Acoustics. New York: Elsevier Inc., 2006.

[16] Kuttruff H. Room Acoustics, New York: Elsevier Science Publishing, 1991.

[17] Kabil, Ö. Eğitim yapılarındaki iç mekânların bilgisayar simülasyon yöntemi ile akustik açıdan incelenmesi, değerlendirilmesi ve düzenlenmesi: KTÜ örneği. Yüksek Lisans Tezi, Karadeniz Teknik Üniversitesi Fen Bilimleri Enstitüsü, Trabzon, Türkiye, 2018. 